\title{
How Do Firms Respond to Hiring Difficulties? Evidence from the Federal Reserve Banks' Small Business Credit Survey
}

\author{
Ellyn Terry, Mels de Zeeuw
}

Federal Reserve Bank of Atlanta

\section{Primary issue:}

Understanding the sources of mismatch between the labor pool and the needs of firms is important. There can be significant variation in hiring challenges by type of firm, and how a firm responds may depend systematically on the nature of the problem. Data from the Federal Reserve Bank's 2017 Small Business Credit Survey allows for a closer examination of hiring difficulties and firm responses.

\section{Key findings:}

Two-thirds of firms report hiring difficulties, with considerable variation by type of firm. Firms located in rural areas and those seeking to fill non-bachelor's positions in industries that tend to have high turnover-such as leisure and hospitality and construction-were more likely to cite difficulty filling positions. The two most commonly cited hiring challenges are "lack of job specific skills, education, or experience" (63 percent) and "too few applicants" (57 percent). Regardless of the reason for hiring difficulty, the primary response is to increase compensation. Relative to otherwise similar firms, those citing "competition from other employers" or "too few applicants" are more likely to respond by raising wages, while firms that experience difficulty finding candidates with "job-specific skills, education, or experience" were more likely to say they "restructured existing employee responsibilities" or "loosened job requirements or offered more training." These results suggest many firms are facing labor cost increases due to hiring challenges, but they are a mix of both compensation and non-compensation expenses.

\section{Takeaways for practice:}

The results provide insight for policymakers trying to understand the linkage between compensation, labor market tightness, and productivity. While most firms are responding to hiring difficulties by increasing pay, many firms are also devoting significant resources to activities such as training and the restructuring of employee responsibilities. This may lead to lower productivity-at least in the short term. To the extent that labor shortages reflect a skills mismatch, workforce development practitioners need to be aware of the differences across industry, education requirement, and geographic location. Potential responses might include greater collaboration between schools and businesses to better align the skills of the workforce with job requirements. Additionally, targeted efforts in rural communities to boost labor force participation may be particularly beneficial.

Follow Atlanta Fed CED on $y$

\section{The Federal Reserve Bank of Atlanta's Community \& Economic Development (CED) Discussion Paper Series} addresses emerging and critical issues in community development. Our goal is to provide information on topics that wil be useful to the many actors involved in community development-governments, nonprofits, financial institutions, and beneficiaries. Find more research, use data tools, and sign up for email updates at frbatlanta.org/commdev. 


\section{HowDoFirms Respond toHiring Difficulties?}

\section{Evidence from the Federal Reserve Banks' Small Business Credit Survey}

\section{Abstract:}

Using data from the Federal Reserve Banks' 2017 Small Business Credit Survey (SBCS), this paper investigates the various ways in which different types of firms with less than 500 employees experience and address hiring difficulties, including when they decide to increase compensation.

We find significant variation in hiring difficulties by type of firm, and a firm's response appears to depend on the nature of the problem. The most common response is to increase compensation, with firms that experience competition from other employers being the most likely to do so. Other common responses were to engage in nonproduction activities-like training and job restructuring - that may boost longer-run productivity.

The results provide insight for policymakers trying to understand the linkage between compensation, labor market tightness, and productivity. Further, the variation in hiring difficulties across firm industry, education requirement, and geographic location informs economic and workforce development practitioners and policymakers working to develop targeted interventions.

JEL classification: J01, J23, J24, J31, J32

Key words: small business, labor market, hiring difficulty, wages

https://doi.org/10.29338/dp2018-01

\section{About the Authors:}

Ellyn Terry is an economic policy analyst specialist in the Research Department of the Federal Reserve Bank of Atlanta. Her work focuses on labor market issues and small business finance. She holds a bachelor's and a master's degree in economics from Florida State University.

Mels de Zeeuw is a research analyst II for the Federal Reserve Bank of Atlanta's Community and Economic Development (CED) group. Prior to joining the Atlanta Fed, de Zeeuw was a research associate at the Andrew Young School of Policy Studies' Center for State and Local Finance and Fiscal Research Center, where he coauthored various briefs and reports on state and local fiscal policy in Georgia as well as a report on Connecticut's revenue structure. He holds a bachelor of arts in political science and a 
master of arts in American history from Leiden University in the Netherlands. De Zeeuw earned a master's degree in economics from Georgia State University.

Acknowledgments: The authors would like to thank Karen Leone de Nie, Claire Kramer, Melinda Pitts, and John Robertson for their diligent feedback and suggestions, and Jeanne Zimmermann and Odie Swanegan for their editing and design support. Any remaining errors are the sole responsibility of the authors. The views expressed herein are those of the authors, and not necessarily those of the Federal Reserve Bank of Atlanta or the Federal Reserve System.

Comments to the authors are welcome at mels.dezeeuw@atl.frb.org or ellyn.terry@atl.frb.org. 


\section{Introduction}

The theory holds that when labor is in short supply, firms bid up wages to attract and retain talent. However, firms can engage in a variety of tactics besides raising wages to combat tight labor market conditions. Using data from the Federal Reserve Banks' national Small Business Credit Survey (SBCS), we investigate the various ways in which firms with less than 500 employees experience and address hiring difficulties, and, in particular, the factors that affect a firm's decision to increase starting pay. ${ }^{1}$ The results show the relative importance of differing labor supply issues that firms face in today's tight labor market, and which factors lead them to take action.

\section{About the data}

The SBCS is an annual convenience survey conducted by the Community Development offices of all 12 Federal Reserve Banks. The survey collects data on the financing needs, decisions, and outcomes for all but the largest 1 percent of firms. ${ }^{2}$ The SBCS complements existing data collection efforts by the National Federation of Independent Business (NFIB) and the Census Bureau's Survey of Business Owners (SBO) and Annual Survey of Entrepreneurs (ASE). ${ }^{3}$

The data in this discussion paper derive from the special question segment of the 2017 SBCS, conducted between September and December of 2017, and reflect responses from 5,621 employer firms in 50 states and the District of Columbia. ${ }^{4}$ The data are weighted to be representative of the 1- to 499-employee population of small businesses. For greater methodological detail on the survey, see the prior year's Report on Employer Firms. ${ }^{5}$

We first asked respondents, "Has your business attempted to hire in the past 12 months?" If the answer was yes, firms were asked how difficult it was to fill jobs that require less than a bachelor's degree ("non-bachelor's") versus jobs that require a bachelor's degree or higher ("bachelor's+"). ${ }^{6}$ Two follow-up questions then inquired about only the type of job (non-bachelor's or bachelor's+) the firm had the most trouble filling: (1) "What about the applicant pool or hiring environment has made it

\footnotetext{
${ }^{1}$ Throughout this discussion paper, we use logistic regressions with controls for firm, industry, and other characteristics to isolate the effects of the specified factors. We summarize the results in the appendix.

2 This includes non-employers and employer firms with less than 500 employees. Firms with less than 500 employees employ about half of non-self-employed workers, according to the U.S. Census Bureau's 2015 Statistics of U.S. Businesses.

${ }^{3}$ The SBO is released every five years, and its most recent data cover 2012. However, its coverage of small business financing is limited. The annual ASE allows for a more in-depth analysis of small business financing, but it does not cover non-employer firms. Its most recent data cover 2015. The monthly NFIB Economic Trends, while frequent and timely, are not representative of the employer firm population in the United States.

${ }^{4}$ Subsequent reports, including reports on employer and non-employer firms, will be released throughout the year. A list of previously published reports is here.

${ }^{5}$ The methodological section of the 2016 Small Business Credit Survey Report on Employer Firms is here.

${ }^{6}$ Firms were asked separately about hiring for jobs that did and did not require a bachelor's degree. The response options were: "not difficult," "somewhat difficult," "very difficult," "Unsure," or "Not applicable."
} 
difficult to fill?" and (2) "What changes has your business made in response to the difficulty?"7 Finally, the SBCS gathered information on the education level of the majority of employees at the firm.

\section{Factors Associated with Hiring Difficulties}

Of firms with job openings, about two-thirds indicated they experienced at least some difficulty hiring. Firms that attempted to fill positions requiring less than a bachelor's degree were about as likely to have trouble hiring as those with jobs requiring a bachelor's degree or higher (see figure 1).

The factors significantly associated with hiring difficulty include: ${ }^{8}$

\section{Unemployment rate}

We find a state's unemployment rate significantly related to the likelihood of experiencing hiring difficulties when filling jobs that did not require a bachelor's degree. The lower the state unemployment rate among people with less than a bachelor's degree, the higher the probability a firm experienced hiring difficulties when attempting to fill a nonbachelor's position.

\section{Figure 1: Share of Firms Experiencing Hiring Difficulty by Level of Education Required}

\author{
Non-bachelor's \\ $(n=3,645)$ \\ Bachelor's+ \\ $(n=2,493)$
}

$67 \%$

\section{Firm characteristics (industry, average education of workforce, age of business)}

Compared to firms in the education or health care industries, firms operating in construction, leisure and hospitality, and other services industries are significantly more likely to say they experienced hiring difficulties when recruiting non-bachelor degree staff. Firms that primarily employ people with less than a bachelor's degree are more likely to experience hiring difficulties compared to firms that primarily employ people with a bachelor's degree or higher when hiring for either type of job (nonbachelor's or bachelor's+).

One reason that may explain both of these findings is variation in hiring and separation rates. Firms in industries that tend to have greater turnover may experience greater hiring difficulties compared to those in low turnover industries, due to the need to do more hiring in general. In fact, the leisure and hospitality and construction industries have the highest hiring and separation rates,

\footnotetext{
${ }^{7}$ Firms that indicate equal difficulty filling non-bachelor's and bachelor's+ jobs were asked only about non-bachelor's. In order to reduce potential bias, none of our model results that estimate reasons for or responses to hiring difficulties include these firms. The response options for the first follow-up question were: "Too few applicants," "Competition from other employers," "Lack of basic math, reading, or writing skills," "Lack of soft skills," "Lack of job-specific skills, education, or experience," "Difficulty passing background check or credit check," "Difficulty passing drug test," "Other," "Unsure." The response options for the second follow-up question were: "Made no changes," "Increased starting pay," "Loosened job requirements or offered more training," "Restructured existing employee responsibilities," "Invested more in labor-saving technologies," "Enhanced benefits or increased non-wage compensation," "Other," "Unsure."

${ }^{8}$ See table 1 in the appendix for the full logistic regression results.
} 
according to data from the U.S. Bureau of Labor Statistics, and these industries are most likely to indicate hiring difficulties for non-bachelor's degree positions. ${ }^{9}$ Additionally, the majority of employees working in leisure and hospitality, construction, and other services do not have bachelor's degrees. Therefore, these two factors may both be indicative of a firm that tends to hire frequently. ${ }^{10}$ Interestingly, there were not significant differences across industries among firms recruiting staff with a bachelor's degree or higher.

\section{Location}

Regardless of the education level firms were recruiting for, those located in rural areas are more likely than those in urban areas to have trouble hiring. This differential may be related to a shrinking rural labor pool, partially because of lower labor force participation rates (LFP) in rural areas. For example, in mid-2017 the prime-age rural LFP rate was 3 percentage points below that of metro areas. Rural area LFP has also declined relatively rapidly over the last decade. ${ }^{11}$

\section{Reasons for Hiring Difficulty}

The two most frequently reported reasons for hiring difficulty were (1) lack of job-specific skills, education, or experience and (2) too few applicants (see figure 2 ). ${ }^{12}$

For brevity, we discuss only the reasons we find related to the likelihood a firm decides to raise starting pay (see section 4). ${ }^{13}$ These reasons include: (1) too few applicants, (2) competition from other employers, (3) lack of math, reading, or writing skills, and (4) difficulty passing background or credit check, or drug tests.

\section{Unemployment and type of job}

The impact of a state's unemployment rate can be difficult to

\section{Figure 2: Reasons for Hiring Difficulties $(n=3,180)$}

Lack of job-specific skills, education, or experience

Too few applicants

Lack of soft skills

Competition from other employers

Difficulty passing background check, credit check, or drug test

Lack of basic math, reading, or writing skills

Note: Some 3\% selected "Other." Respondents could select multiple options. Source: 2017 Federal Reserve Banks' Small Business Credit Survey interpret, since it can reflect both cyclical and structural differences between states. For example, a smaller share of Mississippi's population has a college degree, so we would expect its unemployment

\footnotetext{
9 That is according to 17-year average hire and separation rates for each industry using data from the Bureau of Labor Statistics' Job Openings and Labor Turnover Survey.

10 In the SBCS, 91 percent of firms in construction, 94 percent of firms in leisure and hospitality, and 88 percent of firms in other services indicated their staff were majority non-bachelor's.

11 This is true among people who do not have bachelor's degrees. See "Labor Market Outcomes in Metropolitan and NonMetropolitan Areas: Signs of Growing Disparities," "Labor Supply Constraints and Health Problems in Rural America" and "슨 View of the U.S. Economy and Rural and Urban Labor Market Dynamics."

12 In a recent report by the NFIB, 62 percent of firms with less than 250 employees cited a "Lack of experience" or "Lack of jobspecific or occupational skills" as the most important reason for an applicant being unqualified.

${ }^{13}$ See table 2 in the appendix for the full logistic regression results.
} 
rate to tend to be higher than the national average. To tease out these two effects, we separate the unemployment rate into its demographic and non-demographic components. ${ }^{14} \mathrm{We}$ find firms are much more likely to report issues with job candidates passing background checks, credit checks, or drug tests when they are located in a state with a higher than average unemployment rate due to a lower than average educational attainment.

Firms are more likely to report "too few applicants" if they are in a state with a relatively lower demographically adjusted unemployment rate than the U.S. rate (see table 1 below). ${ }^{15}$ Interestingly, the demographically adjusted unemployment rate is also associated with a firm's likelihood of citing lack of math, reading, or writing skills as a reason. This could reflect structural differences between states, such as education policies.

\section{Table 1: Impact of State Unemployment Rate on Selected Reasons for Hiring Difficulty} $(n=2,263)$

\begin{tabular}{|l|c|c|c|c|}
\hline & $\begin{array}{c}\text { Too few } \\
\text { applicants }\end{array}$ & $\begin{array}{c}\text { Competition } \\
\text { from other } \\
\text { employers }\end{array}$ & $\begin{array}{c}\text { Lack of math, } \\
\text { reading, or writing } \\
\text { skills }\end{array}$ & $\begin{array}{c}\text { Background, } \\
\text { credit check, or } \\
\text { drug test }\end{array}$ \\
\hline $\begin{array}{l}\text { Demographically Adjusted State } \\
\text { Unemployment Rate }\end{array}$ & $-0.059^{*}$ & -0.009 & $0.047^{* *}$ & 0.004 \\
\hline $\begin{array}{l}\text { Demographic Component of State } \\
\text { Unemployment Rate }\end{array}$ & -0.082 & -0.112 & 0.020 & $0.217^{* *}$ \\
\hline
\end{tabular}

Source: 2017 Federal Reserve Banks' Small Business Credit Survey

While firms that attempted to hire for non-bachelor's positions were slightly less likely to report hiring difficulties overall, they were relatively more likely to cite too few applicants, lack of soft skills, and difficulty passing background checks as reasons. This differential persists even when controlling for differences in firm characteristics (see figure 3). ${ }^{16}$

\footnotetext{
${ }^{14}$ To calculate the part of the unemployment rate due to demographic differences, we (1) calculate the difference in the share of the population in a particular demographic group and the United States (for example, the share of 25- to 54-year-olds with less than a high school diploma in Alabama minus the share of 25- to 54-year-olds in the United States). (2) We calculate the difference in the unemployment rate between the group and everyone (that is, the unemployment rate of 25- to 54-year-olds in the United States minus the U.S. unemployment rate. (3) We multiply these differences together. (4) We sum these numbers for each demographic group. The demographic effect ranges between -0.68 in Washington, DC, to 0.26 in Nevada. To calculate the non-demographic component, we subtract the demographic component from the state's unemployment rate.

${ }^{15}$ The NFIB's monthly small business Economic Trends also shows the share of firms reporting none or too few applicants is highly cyclical.

${ }^{16}$ We do not find educational requirements are significantly associated with a firm's probability of citing "lack of job-specific skills, education, or experience" or "competition from other employers" as reasons for hiring difficulty.
} 


\section{Figure 3: Reasons for Hiring Difficulties, by Level of Education Required Holding Fixed Other Factors $(n=2,263)$}

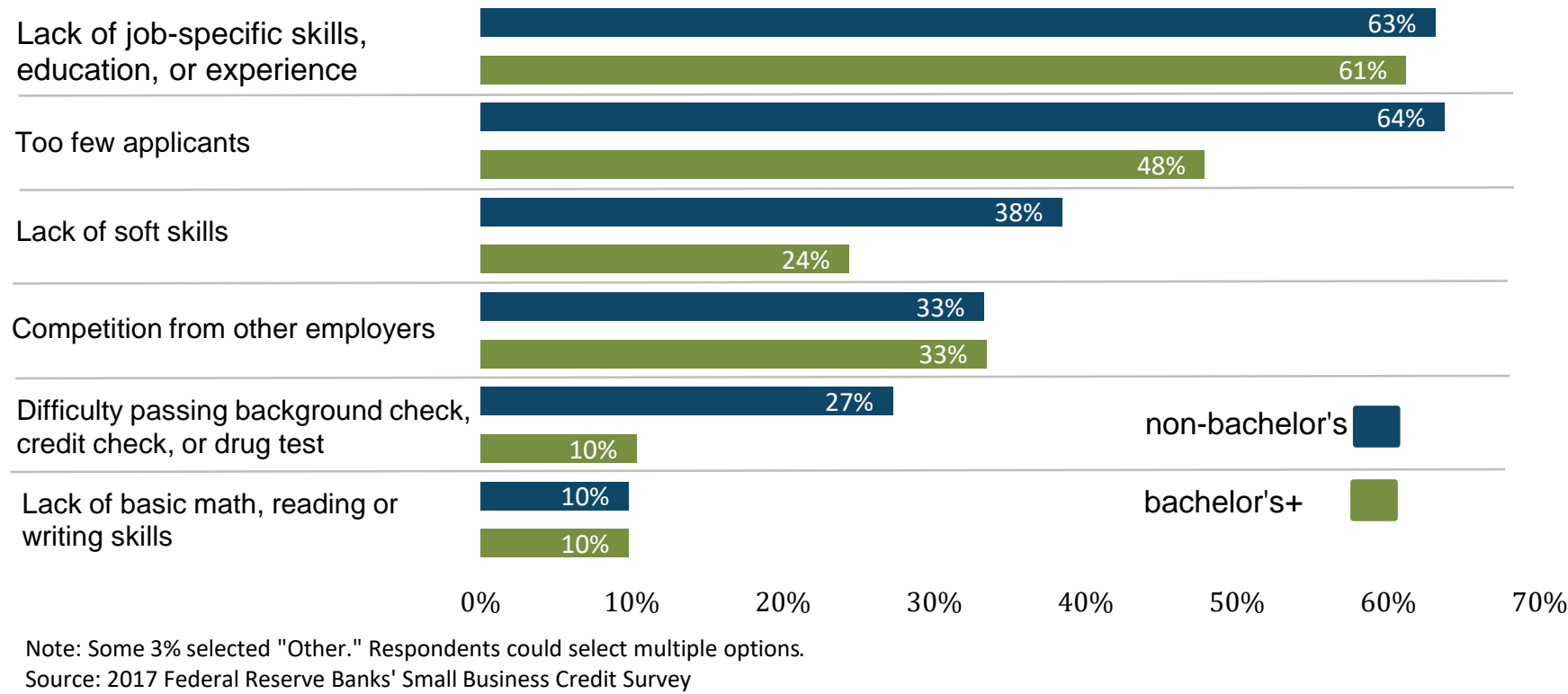

\section{Firm characteristics (size, age, and industry)}

The larger the firm, the more likely it was to report competition from other employers as a reason for hiring difficulty, and these differences persist even when controlling for other factors. For example, firms with 50 to 499 employees were twice as likely to cite competition from other employers compared to firms with 1 to 4 employees, all else being equal (see figure 4 ).

\section{Location}

Further, firms that reside in rural areas are significantly more likely to state their applicant pool is too small, which as discussed above may be related to lower labor force participation rates in rural areas (see figure 5).

\section{Figure 4: Share of Firms That Cite Competition from Other Employers, by Firm Size Holding Fixed Other Factors $(n=2,263)$}

\section{Figure 5: Share of Firms That Cite Too Few Applicants, by Location Holding Fixed Other Factors $(n=2,263)$}
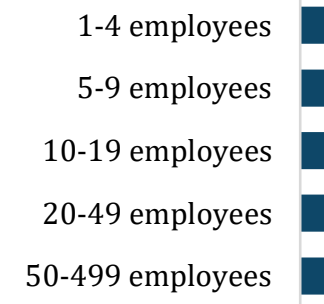

$25 \%$
Urban

$42 \%$

\section{$31 \%$}

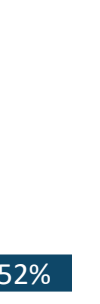

\section{$57 \%$}

Rural

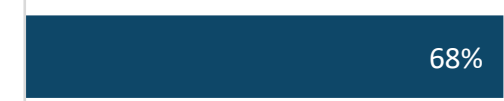




\section{Responses to Hiring Difficulty}

Despite anecdotes and news stories about creative ways firms address labor shortages, it appears raising wages still top the list when it comes to attracting new talent. The most common response to hiring difficulties is to increase compensation. Half responded by increasing wage or non-wage compensation. Fortyfour percent of firms increased starting pay and 20 percent increased non-wage compensation (see figure 6). Fourteen percent did both.

Economic theory also suggests that a firm's response to a labor supply shortage may be to reduce its need for additional employees. Thirty-two percent restructured existing employee responsibilities, while 18 percent invested in labor-saving technologies. ${ }^{17}$ However, these efforts did not preclude such firms from spending more on their employees. About half of these firms also indicated they were increasing starting pay or benefits. Just 17 percent of firms indicated they made no changes at all in the face of hiring difficulties.

The factors most important to a firm's decision to increase compensation were:

\section{Firm characteristics (size and age)}

We find firm size is related to inaction in the face of hiring challenges. Even when controlling for other factors, the smallest firms are more than twice as likely as large firms not to take action (see figure 7). We find firm size is also positively related to all measures that would likely bear the greatest financial costs. They include boosting benefits, raising starting pay, or making capital or technology investments. This may indicate small firms lack a financial buffer that would better position them to take on the cost or risk associated with these particular actions.

\footnotetext{
${ }^{17}$ Nine percent of firms selected both options.
} 


\section{Figure 7: Share of Firms That Made No Changes, by Firm Size Holding Fixed Other Factors}

$(n=2,245)$

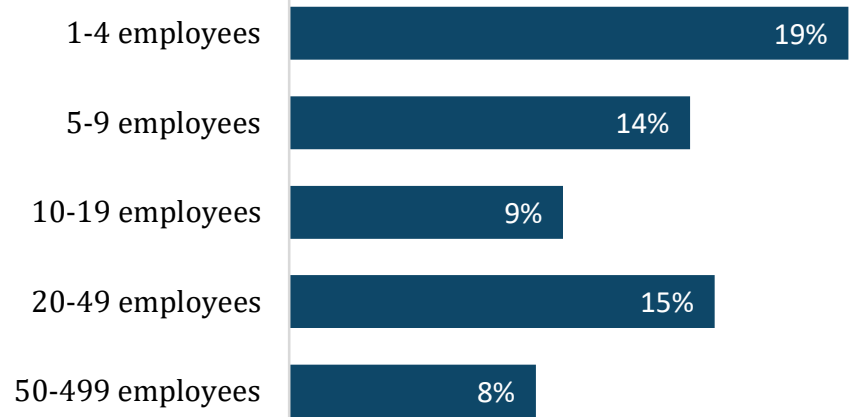

Source: 2017 Federal Reserve Banks' Small Business Credit Survey

\section{Reasons for hiring difficulty}

Other factors related to a firm's decision to increase compensation were a small applicant pool as well as facing competition from other employers. Both of these we find inversely correlated with a state's unemployment rate. This seems in line with economic theory; as the availability of workers narrows, and hiring competition gets increasingly fierce, wages rise.

To a lesser extent, firms that encounter candidates lacking basic math, reading, or writing skills or that have trouble passing credit checks, background checks, or drug tests are more likely to respond by raising pay than firms that are not encountering these issues. This may indicate greater compensation is needed to attract higher-quality workers. Surprisingly, the candidate pool lacking soft skills or job-specific skills, education, or experience was uncorrelated with increasing starting pay. These two reasons were correlated, however, with a firm's use of training and with strategic restructuring of existing employee responsibilities.

\section{Conclusion}

Overall, about two-thirds of firms in the 2017 SBCS experienced hiring difficulties in the prior 12 months. Firms in industries that tend to have higher turnover-such as leisure and hospitality and construction-are more likely to cite hiring difficulties for positions that don't require a bachelor's degree. Firms in rural areas are more likely to have trouble hiring, regardless of the education level needed.

Two-thirds of firms that experience difficulty filling non-bachelor's positions cite "too few applicants" as a reason, and we find this reason is inversely correlated with a state's demographically adjusted unemployment rate.

Overall, about half of firms indicated they increased compensation-either by raising starting pay or enhancing benefits or non-wage compensation-in response to hiring difficulties. The most influential factors behind a firm's decision to do so were competition for talent and having "too few 
applicants." On average, a firm was 20 percent more likely to have raised starting pay and 13 percent more likely to increase benefits or non-wage compensation in response to hiring difficulties if they selected "competition from other employers." Firms that indicated "too few applicants" were, on average, 10 percent more likely to raise starting pay and 7 percent more likely to increase benefits or non-wage compensation.

The most commonly cited reason for hiring difficulties, "lack of job specific skills, education, or experience," was unrelated to a firm's decision to increase either type of compensation. However, these firms were more likely to say they "restructured existing employee responsibilities" or "loosened job requirements or offered more training" in response. Thus, while most firms are responding to hiring difficulties by increasing compensation, many firms are also devoting significant resources to activities such as training and the restructuring of employee responsibilities. This may lead to lower productivityat least in the short term.

The results have implications for workforce development practitioners and policymakers. To the extent that labor shortages reflect a skills mismatch, differences in hiring difficulties across industry, education requirement, and geographic location can help inform interventions. Potential responses might include greater collaboration between schools and businesses to better align the skills of the workforce with job requirements. Additionally, targeted efforts in rural communities to boost labor force participation may be particularly beneficial. 


\section{Appendix}

Table 2: Relative Likelihood of Facing Hiring Difficulties by Level of Education Required 18

\begin{tabular}{lcc} 
& $\begin{array}{c}\text { Hiring } \\
\text { difficulties } \\
\text { for non- } \\
\text { bachelor's }\end{array}$ & $\begin{array}{c}\text { Hiring } \\
\text { difficulties } \\
\text { for } \\
\text { bachelor's }\end{array}$ \\
Covariates & & \\
\hline Number of employees, compared to 1-4 employees & -0.010 & 0.034 \\
5-9 employees & 0.021 & -0.007 \\
10-19 employees & 0.053 & $0.091^{*}$ \\
20-49 employees & 0.024 & 0.047 \\
50-499 employees & & \\
Age of business, compared to $<2$ years & $0.110^{* *}$ & 0.017 \\
3-5 years & $0.146^{* * *}$ & 0.019 \\
6-10 years & $0.146^{* * *}$ & 0.012 \\
11-15 years & $0.131^{*}$ & -0.007 \\
16-20 years & $0.215^{* * *}$ & $0.101^{* *}$ \\
21+ years & & \\
Industry, compared to Education/Health & $0.086^{*}$ & 0.002 \\
Trade, transportation and utilities & $0.113^{* *}$ & -0.058 \\
Manufacturing & $0.219^{* * *}$ & 0.059 \\
Construction & $0.170^{* * *}$ & 0.076 \\
Leisure and hospitality & 0.093 & 0.093 \\
Financial activities & $0.111^{* *}$ & 0.016 \\
Professional and business services & $0.223^{* * *}$ & 0.001 \\
Other services & 0.037 & 0.046 \\
Information & 0.158 & -0.020 \\
Agriculture, mining and logging & & \\
Other factors & & \\
Located in rural area & $0.073^{* * *}$ & $0.086^{* *}$ \\
Majority of employees at firm have less than a bachelor's & $0.229^{* * *}$ & $0.070^{* *}$ \\
Profitable, end of 2016 & -0.031 & 0.037 \\
Planning to expand workforce, next 12 months & $0.061^{* *}$ & 0.025 \\
State unemployment rate (non-BA) & $-0.024^{* *}$ & \\
State unemployment rate (BA+) & & -0.023 \\
Observations & & \\
\hline & & 2,243 \\
\hline
\end{tabular}

${ }^{* * *} \mathrm{p}<0.01 .{ }^{* *} \mathrm{p}<.05,{ }^{*} \mathrm{P}<0.1$

${ }^{18}$ Results are from a logistic regression. Coefficients are displayed as average marginal effects. 
Table 3: Relative Likelihood of Citing Each Reason for Hiring Difficulty19

\begin{tabular}{|c|c|c|c|c|c|c|}
\hline Covariates & $\begin{array}{l}\text { Too few } \\
\text { applicants }\end{array}$ & $\begin{array}{l}\text { Competition } \\
\text { from other } \\
\text { employers }\end{array}$ & $\begin{array}{l}\text { Lack of math, } \\
\text { reading, or } \\
\text { writing skills }\end{array}$ & $\begin{array}{l}\text { Lack of soft } \\
\text { skills }\end{array}$ & $\begin{array}{l}\text { Lack of job- } \\
\text { specific } \\
\text { skills, } \\
\text { education or } \\
\text { experience }\end{array}$ & $\begin{array}{l}\text { Background, } \\
\text { credit check, } \\
\text { or drug test }\end{array}$ \\
\hline \multicolumn{7}{|c|}{ Number of employees, compared to $1-4$ employees } \\
\hline 5-9 employees & 0.042 & $0.063^{*}$ & $-0.073^{* *}$ & 0.016 & -0.036 & 0.034 \\
\hline 10-19 employees & 0.048 & $0.170^{* * *}$ & -0.054 & 0.041 & 0.014 & 0.067 \\
\hline 20-49 employees & 0.070 & $0.157^{* * *}$ & $-0.117 * * *$ & -0.060 & -0.053 & 0.041 \\
\hline 50-499 employees & 0.064 & $0.261^{* * *}$ & $-0.086^{*}$ & -0.037 & -0.048 & $0.210 * * *$ \\
\hline \multicolumn{7}{|c|}{ Age of business, compared to $0-2$ years } \\
\hline 3-5 years & 0.108 & -0.101 & 0.014 & -0.009 & 0.015 & -0.064 \\
\hline $6-10$ years & $0.113^{* *}$ & -0.083 & -0.004 & -0.064 & 0.069 & 0.014 \\
\hline $11-15$ years & 0.075 & 0.065 & -0.071 & -0.031 & 0.032 & 0.007 \\
\hline $16-20$ years & 0.026 & -0.028 & 0.013 & -0.046 & 0.025 & 0.005 \\
\hline $21+$ years & 0.064 & -0.060 & 0.063 & -0.062 & 0.089 & 0.058 \\
\hline \multicolumn{7}{|c|}{ Industry, compared to Education/Health } \\
\hline Trade, transportation and utilities & -0.009 & $-0.170 * *$ & -0.009 & 0.039 & 0.045 & 0.054 \\
\hline Manufacturing & $-0.103^{*}$ & -0.101 & 0.070 & -0.011 & $0.122^{*}$ & 0.023 \\
\hline Construction & -0.011 & -0.072 & -0.014 & -0.089 & $0.168^{* *}$ & $0.175^{* * *}$ \\
\hline Leisure and hospitality & 0.096 & -0.083 & 0.037 & 0.052 & 0.035 & $0.082^{*}$ \\
\hline Financial activities & -0.025 & -0.048 & 0.020 & -0.032 & 0.126 & 0.043 \\
\hline Professional and business services & 0.033 & -0.030 & -0.010 & -0.001 & 0.079 & 0.052 \\
\hline Other services & 0.056 & $-0.123^{*}$ & 0.019 & -0.017 & 0.136 & 0.042 \\
\hline Information & -0.060 & -0.175 & -0.028 & 0.075 & -0.005 & -0.036 \\
\hline Agriculture, mining and logging & -0.024 & 0.072 & -0.094 & 0.040 & -0.067 & 0.040 \\
\hline \multicolumn{7}{|l|}{ Other factors } \\
\hline Located in rural area & $0.102 * *$ & 0.000 & $-0.054 *$ & -0.026 & -0.043 & 0.041 \\
\hline Hiring for a non-bachelor's job & $0.153^{* * *}$ & -0.002 & $0.113^{* * *}$ & $0.139 * * *$ & 0.019 & $0.170 * * *$ \\
\hline $\begin{array}{l}\text { Profitable, end of } 2016 \\
\text { Planning to expand workforce, next }\end{array}$ & \multicolumn{5}{|c|}{ Planning to expand workforce, next } & -0.040 \\
\hline 12 months & -0.046 & $0.094 * * *$ & -0.012 & -0.006 & 0.001 & 0.039 \\
\hline $\begin{array}{l}\text { Demographically adjusted state } \\
\text { unemployment rate }\end{array}$ & $-0.059^{*}$ & -0.009 & $0.047^{* *}$ & 0.009 & 0.021 & 0.004 \\
\hline $\begin{array}{l}\text { Demographic component of state } \\
\text { unemployment rate }\end{array}$ & -0.082 & -0.112 & 0.020 & 0.008 & 0.049 & $0.217^{* *}$ \\
\hline Observations & 2,263 & 2,263 & 2,263 & 2,263 & 2,263 & 2,263 \\
\hline
\end{tabular}

${ }^{19}$ Results are from a logistic regression. Coefficients are displayed as average marginal effects. 
Table 4: Relative Likelihood of Citing Each Response to Hiring Difficulty20

\begin{tabular}{|c|c|c|c|c|c|c|}
\hline Covariates & $\begin{array}{l}\text { Made no } \\
\text { changes }\end{array}$ & $\begin{array}{l}\text { Increased } \\
\text { starting } \\
\text { pay }\end{array}$ & $\begin{array}{l}\text { Loosened job } \\
\text { requirements } \\
\text { or offered } \\
\text { more training }\end{array}$ & $\begin{array}{l}\text { Restructured } \\
\text { existing } \\
\text { employee } \\
\text { responsibilities }\end{array}$ & $\begin{array}{l}\text { Invested } \\
\text { more in labor- } \\
\text { saving } \\
\text { technologies }\end{array}$ & $\begin{array}{l}\text { Enhanced benefits } \\
\text { or increased } \\
\text { non-wage } \\
\text { compensation }\end{array}$ \\
\hline 5-9 employees & $-0.056^{*}$ & $0.089 * *$ & 0.038 & -0.012 & 0.019 & $0.116 * * *$ \\
\hline 10-19 employees & $-0.104 * * *$ & $0.137 * * *$ & $0.100 * *$ & 0.082 & 0.025 & $0.105^{* * *}$ \\
\hline \multicolumn{7}{|l|}{ Age of business, compared to $<2$ years } \\
\hline 3-5 years & -0.081 & $0.162 * *$ & -0.025 & $0.123 * * *$ & $0.072 *$ & 0.040 \\
\hline $6-10$ years & $-0.104^{* *}$ & $0.123 * *$ & -0.023 & 0.043 & 0.046 & $0.078 *$ \\
\hline $11-15$ years & -0.033 & $0.142 * *$ & -0.012 & 0.058 & $0.117^{* *}$ & 0.056 \\
\hline $16-20$ years & 0.002 & $0.156^{* *}$ & -0.062 & 0.081 & 0.071 & $0.080^{*}$ \\
\hline Manufacturing & $-0.073 *$ & 0.008 & 0.019 & -0.001 & 0.073 & -0.045 \\
\hline Construction & -0.019 & 0.023 & 0.036 & -0.025 & 0.051 & 0.002 \\
\hline Leisure and hospitality & -0.056 & 0.002 & 0.043 & $0.141 * *$ & -0.023 & -0.078 \\
\hline Financial activities & -0.076 & 0.091 & 0.026 & 0.059 & 0.104 & 0.017 \\
\hline Professional and business services & 0.003 & 0.033 & 0.011 & -0.048 & 0.004 & -0.034 \\
\hline Other services & -0.026 & -0.027 & $0.138^{*}$ & -0.047 & 0.005 & 0.021 \\
\hline Information & $0.278 * *$ & -0.064 & 0.055 & $-0.165^{* *}$ & 0.018 & -0.019 \\
\hline Agriculture, mining and logging & -0.055 & 0.016 & -0.058 & -0.033 & 0.085 & -0.094 \\
\hline \multicolumn{7}{|l|}{ Other factors } \\
\hline Located in rural area & 0.022 & 0.051 & 0.019 & -0.016 & -0.017 & -0.046 \\
\hline $\begin{array}{l}\text { Demographic component of state } \\
\text { unemployment rate }\end{array}$ & 0.095 & -0.141 & -0.026 & -0.081 & 0.049 & 0.023 \\
\hline \multicolumn{7}{|l|}{ Reasons for Hiring Difficulties } \\
\hline Too few applicants & -0.045 & $0.101 * * *$ & 0.045 & $0.068 *$ & 0.009 & $0.072 * *$ \\
\hline Competition from other employers & $-0.094 * * *$ & $0.200 * * *$ & $0.060 * *$ & 0.018 & 0.028 & $0.132 * * *$ \\
\hline $\begin{array}{l}\text { Lack of basic math, reading, or } \\
\text { writing skills }\end{array}$ & $-0.102 *$ & $0.079 *$ & $0.108^{* *}$ & $0.148^{* * *}$ & $0.141^{* * *}$ & $0.062^{*}$ \\
\hline Lack of soft skills & $-0.062 * *$ & -0.022 & $0.080 * *$ & $0.119 * * *$ & $0.054 * *$ & $0.049 *$ \\
\hline $\begin{array}{l}\text { Lack of job-specific skills, } \\
\text { education, or experience } \\
\text { Difficulty passing background }\end{array}$ & -0.038 & -0.014 & $0.108^{* *}$ & $0.109 * * *$ & 0.034 & -0.019 \\
\hline check, credit check, or drug test & -0.049 & $0.074 * *$ & 0.018 & -0.010 & 0.027 & $0.040^{*}$ \\
\hline Observations & 2,245 & 2,245 & 2,245 & 2,245 & 2,245 & 2,245 \\
\hline
\end{tabular}

\footnotetext{
${ }^{20}$ Results are from a logistic regression. Coefficients are displayed as average marginal effects.
} 